\title{
Systematic Nutrient (im) Balances in Dairy Farm Systems of the Northeast and Mid-Atlantic Regions of the United States
}

\author{
Quirine M. Ketterings ${ }^{1}$, Karl J. Czymmek ${ }^{1}$, Douglas B. Beegle ${ }^{2}$, Larry E. Chase ${ }^{1} \&$ Caroline N. Rasmussen $^{1}$ \\ ${ }^{1}$ Department of Animal Science, Department of Animal Science, Cornell University, Ithaca NY, USA \\ ${ }^{2}$ Department of Plant Science, Pennsylvania State University, University Park, PA, USA \\ Correspondence: Quirine M. Ketterings, Department of Animal Science, 323 Morrison Hall, Cornell University, \\ Ithaca NY 14853, USA. Tel: 1-607-255-3061. E-mail: qmk2@cornell.edu
}

Received: June 13, 2012 Accepted: June 28, 2012 Online Published: October 12, 2012

doi:10.5539/jas.v4n11p1 URL: http://dx.doi.org/ doi:10.5539/jas.v4n11p1

\begin{abstract}
Many governmental programs that address non-point source pollution from animal feeding operations havefocussed on promoting land-based best management practices (BMPs). Our objectives were to illustrate and quantify nitrogen $(\mathrm{N})$ and phosphorus (P) balances of Northeast and Mid-Atlantic dairy farms using (1) a hypothetical and representative Northeastern and Mid-Atlantic dairy farm, and (2) three case study dairy farms with animal densities of 1.6 to 2.4 milking cows ha ${ }^{-1}$. Analyses of $\mathrm{N}$ and $\mathrm{P}$ balances for the representative farm showed an annual surplus of $258 \mathrm{~kg} \mathrm{~N}$ and $31 \mathrm{~kg} \mathrm{P}_{2} \mathrm{O}_{5} \mathrm{ha}^{-1}$. For the three case study farms, $65-73 \%$ of the $\mathrm{N}$ and 41-62\% of the $\mathrm{P}$ that entered the farm through feed, fertilizer, fixation, animal purchases and/or bedding were not exported in the form of milk, animals or crops, resulting in excesses of 114-248 kg N ha ${ }^{-1}$ and $37-42 \mathrm{~kg} \mathrm{P}_{2} \mathrm{O}_{5}$ ha ${ }^{-1}$. These quantifications suggest that land-based BMPs to address non-point source pollution will fall short of expectations over the long-term because they do not recognize the strategic issues faced by many of today's dairy farmers in the Northeast and Mid-Atlantic regions. We conclude that for the long-term sustainability of the dairy industry, a land-based BMP approach should be complimented with whole farm nutrient mass balance assessments and address nutrient source reduction and/or manure treatment and export. The latter requires a change in cropping systems and/or innovative systems to treat the manure to decrease transport costs and/or add economic value.
\end{abstract}

Keywords: agricultural environmental management, agricultural policy, dairy and livestock farms, Northeast and Mid-Atlantic USA, whole farm nutrient balance, systems analyses

\section{Introduction}

Market-based economics have resulted in an organizational pattern in modern dairy production whereby a significant proportion of feed for the dairy animals is purchased rather than grown on the land to which byproducts are applied (Kellogg et al., 2000). This feed (usually grain-based) may be produced on other land nearby, but for dairies in the Northeast and Mid-Atlantic regions of the United States of America (USA), this feed is generally produced on land long distances away (such as in the Midwestern USA).

Typically, the majority of dairy farm nutrients is brought onto the farm via feed and fertilizer. In the case of $\mathrm{N}$, additional imputs include $\mathrm{N}$ fixation by legumes crops and deposition from the atmosphere. Nutrient exports include milk, animal and crop sales, leaching, denitrification, volatilization, runoff, and erosion. Taking into account nutrient imports through feed, fertilizer, purchased animals, bedding, and $\mathrm{N}$ fixation and exports in the form of sales of milk, crops, and animals (Figure 1), Bloomfield (1998) analyzed five New York (NY) dairy farms representing five general farm management categories: (1) small conventional; (2) large conventional; (3) Amish; (4) organic; and (5) grazing. Four of the five farms had substantial annual nutrient surpluses, regardless of size. The fifth farm, an organic dairy, had a very slight surplus for nitrogen (N)and nearly zero balance for phosphorus (P). At this farm almost all feed was home-grown and virtually no fertilizer was purchased, a highly unusual business model for the region. In another study of three conventional NY dairy farms by Klauser (1993), $64-89 \%$ of the N,Pand $\mathrm{K}$ imported annually onto the farm through feed, fertilizer, purchase animal and $\mathrm{N}$ fixation, could not be accounted for in exports of milk, cattle, feed or crops.As a result of nutrient loss and accumulation, animal agriculture has been implicated in degradation of air quality (NRC, 2003) and water (USEPA, 1996; Cook, 1998). 


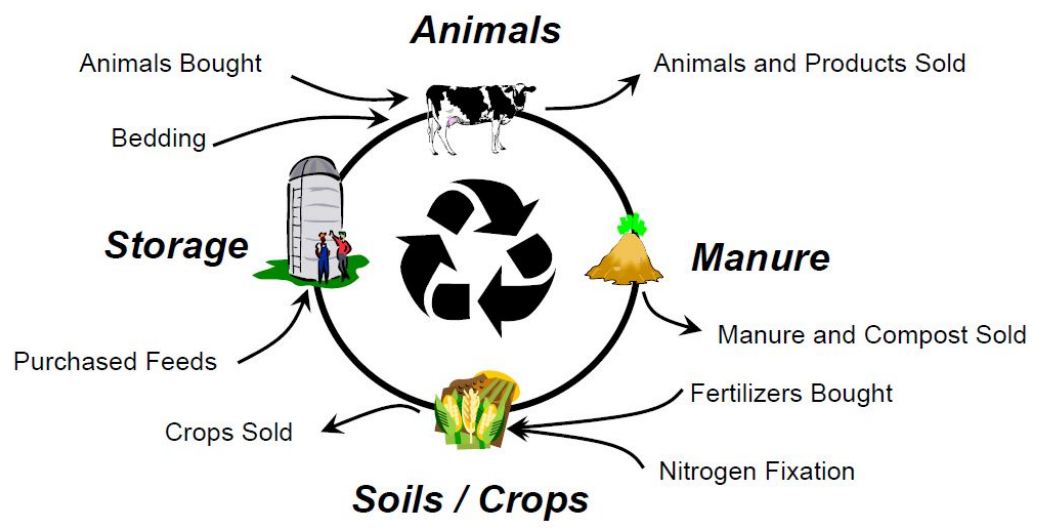

Figure 1.Subcomponents of the dairy farm system

To address nutrient accumulation and losses from dairy farms, management strategies that address nutrient use efficiency should be examined within each of the different subcomponents

Nutrient losses can occur in the barn, the feed storage and the manure storage but much of the difference between managed imports and exports tends to be distributed on farm fields in the form of manure because little economic incentive exists to redistribute the manure offsite (Kellogg et al., 2000). Of the three major nutrients, $\mathrm{N}$ and $\mathrm{P}$ are both water quality concerns (e.g. Lanyon, 2000), while $\mathrm{N}$ is also an air quality concern (USEPA, 2005), so we will focus our whole farm balance assessments on these two nutrients.

Bussink and Oenema (1998) report that ammonia volatilization from the barn floor, manure storage surface, and the fields following land application of manure can result in significant losses of N. Nitrogen applied with manure on the fields may accumulate somewhat in soil organic matter but in the Northeast and Mid-Atlantic regions, much of what is land applied and not volatilized or used by crops during the growing season is lost to the environment due to denitrification or leaching (Kohn et al., 2002).

For P, a significant portion contained in the manure can be stored in the soil but the soil's capacity to store $\mathrm{P}$ is finite. The additional amount of $\mathrm{P}$ that a soil can store decreases with soil test $\mathrm{P}$ buildup over time while the potential for loss of P from the soil increases as soil test P increases (e.g. Kleinman et al., 2000; McDowell \& Sharpley, 2001; Sharpley et al., 2001; Sims et al., 2002; Maguire \& Sims, 2002).

Similar to programs in Europe, concerns about environmental losses of $\mathrm{N}$ and $\mathrm{P}$ in the USA ledto the development of rules for Concentrated Animal Feeding Operations (CAFO rules) under the Clean Water Act (Federal Register, 2003). Similar efforts are now under way in terms of air quality through the Air Quality Consent Agreement with Animal Feeding Operations (USEPA, 2005). Under current CAFO rules, many animal feeding operations in the United States have developed and implemented comprehensive nutrient management plans (CNMPs). These CNMPs, and their annual updates, must be developed in accordance with USDA-NRCS standards and specifications (USDA-NRCS, 2005). At a minimum, the farms must implement best management practices (BMPs) to exclude clean water from animal production areas, collect and treat wastewater and any water that has mixed with waste in the animal production areas, and collect and recycle manure nutrients on crop fields according to Land Grant University guidelines. State and local programs and regulations are currently in place in the Northeast and Mid-Atlantic regions to address these issues.

Several USDA programs are assisting regulated large farms as well as non-regulated smaller farms to implement CNMPs (USDA-NRCS, 2006). Recognition is needed for the need for further development of tools and BMPs as well as policy that addresses $\mathrm{N}$ and $\mathrm{P}$ imbalances.In NY, development and implementation of field-based environmental indicators such as the P runoff index (Czymmek et al., 2003), local initiatives such as the establishment of an on-farm research project on P fertilizer needs of maize (Zea mays L.) (Ketterings et al., 2005), and reduced $P$ levels of dairy ration, have contributed to a greatly improved statewide $P$ balance in the state in the past 10-15 years (Ketterings et al., 2011; 2012). These initiatives illustrate that there are considerable opportunities to reduce nutrient losses from dairy farms, but that a systems approach and policy shift are needed.

Our objectives were to illustrate and quantify current imbalances in Northeast and Mid-Atlantic dairy farms by constructing N and P balances for: (1) a representative Northeastern or Mid-Atlantic dairy farm, and (2) three commercial NY dairy farms. Implications of such imbalances for future policy development are discussed. 


\section{Method}

\subsection{Nutrient Balance for a Representative Northeast and Mid-Atlantic Dairy Farm}

Many Northeast and Mid-Atlantic dairies grow forages (corn silage, grass/alfalfa (Medicago sativa L.) hay or hay silage) on the farm and purchase concentrates (grains). This arrangement offers the key advantage of reducing farm costs in terms of capital and management. Therefore, a "typical" dairy ration was defined as: (1) $50 \%$ DM from forage and 50\% from concentrates such as corn or soybean (Glycine max (L.) Merr.)meal, etc.; and (2) $50 \%$ of the forage DM fed comes from corn silage and $50 \%$ from hay or hay crop silage. A moderately

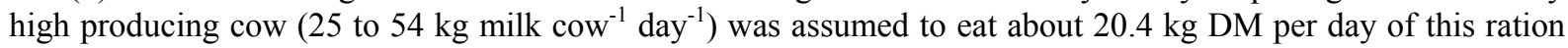
over the course of 12 months. The Cornell Net Carbohydrate and Protein System (Fox et al., 2003) was used to determine $\mathrm{N}$ and $\mathrm{P}$ excretion assuming an average Holstein milking cow bodyweight of $658 \mathrm{~kg}$, a milk production of 25 to $54 \mathrm{~kg} \mathrm{cow}^{-1} \mathrm{day}^{-1}$, and a ration crude protein level of $153-205 \mathrm{~g} \mathrm{~kg}^{-1} \mathrm{DM}$. The Dairy One (2012) forage library was used to determine crop removal of N and P and Land Grant University fertilizer guidelines were used to determine soil N and sod N credits (Cornell Cooperative Extension, 2012; Penn State University, 2012).

\subsection{Whole Farm Balances for Three New York Dairy Farms (Case Studies)}

The three case study farms were selected to obtain a range of $40-60 \%$ of DM imported through feed concentrates and a range in cow densities from 1.6 to 2.3 milking cows ha ${ }^{-1}$. Two of the farms were similar in percentage purchased feed (approximately $40 \%$ ) but differed in animal density (1.6 versus 2.3 milking cows ha ${ }^{-1}$ ). A second farm with an animal density of 1.7 milking cows $\mathrm{ha}^{-1}$ but high percentage purchased feed $(60 \%)$ was also selected. Whole farm nutrient balances were determined as the difference between nutrients imported onto the farm in the form of purchased feed, fertilizer, $\mathrm{N}$ fixation, animals or bedding material minus exports in the form of milk, crops and animals.

Farm financial records and crop and dairy production records were used to provide the necessary import and export quantity and nutrient composition data. Additional information on feed and fertilizer composition was provided by nutritional consultants and feed and fertilizer company representatives. For purchased feed and fertilizer, beginning and ending inventories were taken into account to obtain accurate annual estimates. The contribution of $\mathrm{N}$ fixation was estimated as $60 \%$ of the crude protein in the legume stand if the stand contained more than $90 \%$ legume. For mixed legume/grass stands with $90 \%$ legume or less, $36 \%$ of the total amount of $\mathrm{N}$ was attributed to $\mathrm{N}$ fixation (Heichel, 1986). Nitrogen and P concentrations of $2.9 \%$ and $0.7 \%$, respectively, were assumed for dairy livestock animal (Van Amburgh, personal communication). Milk protein reported to the producer as true protein was converted to crude protein by multiplying by 1.075 (Fox et al., 2003) and this was divided by 6.25 to obtain $\mathrm{N}$ concentration in the milk. The P concentration in milk is not normally reported to the producer so $0.090 \%$ was used based on Knowlton and Herbein (2002).

\section{Results}

\subsection{Nutrient Balance for a Representative Northeast and Mid-Atlantic Dairy Farm}

\subsubsection{Nutrients Excreted in Manure and Urine}

The Cornell Net Carbohydrate and Protein System (Fox et al., 2003) predicted total daily N excretion for an average $658 \mathrm{~kg}$ Holstein milking cow to range from 0.41 to $0.64 \mathrm{~kg}$ excluding the dry period. At a milk production level of 36-39 $\mathrm{kg} \mathrm{cow}^{-1}$ day $^{-1}$, total excretion was estimated at $159 \mathrm{~kg}_{\text {of N } \text { cow }^{-1} \text { year }}{ }^{-1}$ or $0.44 \mathrm{~kg}$ $\operatorname{cow}^{-1}$ day $^{-1}$ of which $55 \%$ was fecal N, and $45 \%$ was urinary N. For the same herd making 36-39 kg of milk cow $^{-1}$ day $^{-1}$, feeding a moderate P level of $4.2 \mathrm{~g} \mathrm{P} \mathrm{kg}^{-1}$ to lactating animals and $3.5 \mathrm{~g} \mathrm{P} \mathrm{kg}^{-1}$ to dry cows, the Cornell Net Carbohydrate and Protein System estimated an annual $\mathrm{P}$ excretion rate of 20.4-22.7 kg of $\mathrm{P}$ cow $^{-1}$ year $^{-1}$ In fertilizer $\mathrm{P}$ equivalents, each mature cow would then excrete about 45-50 $\mathrm{kg} \mathrm{P}_{2} \mathrm{O}_{5}$. Thus, for the average Holstein milking cow, the model predicted that approximately $159 \mathrm{~kg}$ of N and $45 \mathrm{~kg}$ of $\mathrm{P}_{2} \mathrm{O}_{5}$ would be excreted, annually.

\subsubsection{Carrying Capacity and Land Base Required for Forage Production}

The typical ration described above required the dairy producer to feed about 3.7 Mg of forage DM to each cow annually. If we assume $10 \%$ of the DM is lost in the process of mixing/feeding and refusals, and that about $25 \%$ of the DM is lost between harvest and bunk silo storage, the producer must harvest a little over $5.4 \mathrm{Mg}$ of forage DM, excluding safety margins for poor crop years.

Summary data compiled by the National Agricultural Statistics Service (NASS, 2006) indicate that on productive soils in the Northeast and Mid-Atlantic regions, a producer may average a corn silage DM yield of 16.8-17.9 Mg 
$\mathrm{ha}^{-1}$ and an alfalfa or grass hay crop DM yield of 10.1-11.2 $\mathrm{Mg} \mathrm{ha}^{-1}$. A dairy farm with an evenly staggered crop rotation of $4 \mathrm{yr}$ of corn and $4 \mathrm{yr}$ of grass or alfalfa hay would have half its acreage in corn silage and the other half in hay. Given the yields above, an average of about 13.4 to $14.6 \mathrm{Mg} \mathrm{DM} \mathrm{ha}^{-1}$ would be produced across the crop fields and the rotation. Considering the estimates of forage DM needs above, this level of productivity will support 2.5-2.7 milking cows ha ${ }^{-1}$ (Table 1).

Table 1. Farm production characteristics and forage-based carrying capacity of a typical Northeastern or Mid-Atlantic dairy farm

\begin{tabular}{lll}
\hline Production characteristics & & \\
\hline Milk production & $\mathrm{kg} \mathrm{cow}^{-1} \mathrm{day}^{-1}$ & $36-39$ \\
Typical milking cow ration & & \\
Dry matter intake & $\mathrm{kg} \mathrm{cow}^{-1} \mathrm{day}^{-1}$ & 20.4 \\
& $\mathrm{Mg} \mathrm{cow}^{-1} \mathrm{year}^{-1}$ & 7.4 \\
Imported concentrate & $\% \mathrm{DM}^{\text {intake }}$ & 50 \\
Farm produced corn silage & $\% \mathrm{DM}$ intake & 25 \\
Farm produced hay crop & $\% \mathrm{DM}_{\text {intake }}$ & 25 \\
Farm-grown feed (forage) needs & $\mathrm{Mg} \mathrm{cow}^{-1} \mathrm{year}^{-1}$ & 3.7 \\
Feeding loss & $\% \mathrm{DM}^{-1}$ & 10 \\
Harvest and storage loss & $\% \mathrm{DM}^{-1}$ & 25 \\
Farm-grown forage production needs & $\mathrm{Mg} \mathrm{cow}^{-1} \mathrm{year}^{-1}$ & 5.4 \\
Forage yield & & \\
Cornsilage & $\mathrm{Mg} \mathrm{ha}^{-1}$ & $16.8-17.9$ \\
Hay crop & $\mathrm{Mg} \mathrm{ha}^{-1}$ & $10.1-11.2$ \\
Rotationaverage & $\mathrm{Mg} \mathrm{ha}^{-1}$ & $13.4-14.6$ \\
Farm carryingcapacitybasedonforageproduction & $\mathrm{milkcows} \mathrm{ha}^{-1}$ & $2.5-2.7$ \\
\hline
\end{tabular}

4 yr corn silage and 4 yr hay crop rotation.

\subsubsection{Crop Uptake}

An extensive forage analysis database with over 7,000 corn silage samples from NY and Pennsylvania (Dairy One, 2006) showed an average $\mathrm{P}$ concentration of $2.4 \mathrm{~g} \mathrm{P} \mathrm{kg}^{-1}$ and $\mathrm{N}$ concentration of $13.3 \mathrm{~g} \mathrm{~N} \mathrm{~kg}^{-1}$. The nearly $9000 \mathrm{alfalfa} / \mathrm{grass}$ samples in this database averaged $2.9 \mathrm{~g} \mathrm{P} \mathrm{kg}^{-1}$ and $27.2 \mathrm{~g} \mathrm{~N} \mathrm{~kg}^{-1}$. Based on these data, $1.0 \mathrm{Mg}$ of corn silage DM removes about $5.5 \mathrm{~kg}$ of $\mathrm{P}_{2} \mathrm{O}_{5}$ and $13.3 \mathrm{~kg}$ of N, and alfalfa/grass stands remove about $6.7 \mathrm{~kg}$ of $\mathrm{P}_{2} \mathrm{O}_{5}$ and $27.2 \mathrm{~kg}$ of $\mathrm{N}$.

Our example is based on a rotation that includes corn silage yielding 16.8-17.9 $\mathrm{Mg} \mathrm{DM} \mathrm{ha}^{-1}$ and alfalfa/grass yielding 10.1-11.2 $\mathrm{Mg} \mathrm{DM} \mathrm{ha}^{-1}$. Based on these assumptions, corn silage removes about $93 \mathrm{~kg} \mathrm{P}_{2} \mathrm{O}_{5} \mathrm{ha}^{-1}$ while alfalfa/grass removes $71 \mathrm{~kg} \mathrm{P}_{2} \mathrm{O}_{5} \mathrm{ha}^{-1} \mathrm{yr}^{-1}$ resulting in an average annual removal of $82 \mathrm{~kg} \mathrm{P}_{2} \mathrm{O}_{5} \mathrm{ha}^{-1} \mathrm{yr}^{-1}$ over the 8 -yr rotation. Similarly, crop N removal was estimated at $289 \mathrm{~kg} \mathrm{ha}^{-1}$ for the alfalfa/grass stands and $223 \mathrm{~kg} \mathrm{ha}^{-1}$ for the corn silage.

For corn, the net $\mathrm{N}$ requirement must take into account expected contributions from manure and other $\mathrm{N}$ sources. Soils of the Northeast and Mid-Atlantic regions generally contribute at least $45 \mathrm{~kg} \mathrm{~N} \mathrm{ha}^{-1}$ per year to crops and first year corn generally receives sufficient $\mathrm{N}$ from the decomposing sod to meet crop needs that year (Pennsylvania State University, 2012; Cornell Cooperative Extension, 2012). However, a small starter N application is usually recommended independent of cropping or manure history (we assume $34 \mathrm{~kg} \mathrm{~N} \mathrm{ha}^{-1}$ applied with starter for the corn crop, consistent with Land Grant University guidance). Hence, for the corn years in a 4-yr alfalfa/grass and 4-yr corn rotation, approximately $106 \mathrm{~kg} \mathrm{~N} \mathrm{ha}^{-1} \mathrm{yr}^{-1}$ is required. Factoring in a reasonable fertilizer efficiency factor of $65-75 \%$ (Ketterings et al., 2003) recognizing that not all $\mathrm{N}$ applied is taken up by the crop, 140-162 $\mathrm{kg} \mathrm{N} \mathrm{ha}^{-1} \mathrm{yr}^{-1}$ would be required to meet corn crop $\mathrm{N}$ needs over the 4-yr rotation. Alfalfa does not "require" any additional $\mathrm{N}$ for optimum DM production. However, the $\mathrm{N}$-fixing bacteria and the legume 
itself will take up N from manure when provided (Kelling \& Schmitt, 2003) and many dairy producers do apply manure to alfalfa. Assuming that about half of alfalfa/grass N needs can be supplied by manure, about $123 \mathrm{~kg} \mathrm{~N}$ $\mathrm{ha}^{-1}$ of $\mathrm{N}$ could be applied for this part of the rotation. Consequently, a 4-yr corn and 4-yr alfalfa/grass rotation could efficiently utilize an average of approximately $140 \mathrm{~kg} \mathrm{ha}^{-1} \mathrm{yr}^{-1}$.

\subsubsection{Whole Farm Nutrient Mass Balance}

Based on cow needs and the typical rotation as outlined above, 1.0 ha of cropland could feed 2.5 cows and would result in a total excretion of $113 \mathrm{~kg} \mathrm{P}_{2} \mathrm{O}_{5} \mathrm{ha}^{-1} \mathrm{yr}^{-1}$. The crop rotation needed approximately $82 \mathrm{~kg} \mathrm{ha}^{-1} \mathrm{yr}^{-1}$. Thus, the resulting annual surplus would be approximately $31 \mathrm{~kg} \mathrm{P}_{2} \mathrm{O}_{5} \mathrm{ha}^{-1} \mathrm{yr}^{-1}$ as outlined in Table 3 . In terms of N, an average cow excreted about $159 \mathrm{~kg}$ of N or $398 \mathrm{~kg}$ of N ha- ${ }^{-1}$ for 2.5 cows, while the crop rotation needed about $140 \mathrm{~kg} \mathrm{ha}^{-1} \mathrm{yr}^{-1}$. This would result in $258 \mathrm{~kg}$ manure $\mathrm{N} \mathrm{ha}^{-1} \mathrm{yr}^{-1}$ that could not be accounted for in crop uptake (Table 2).

Table 2. Farm manure $\mathrm{N}$ and $\mathrm{P}$ content and crop uptake of a typical Northeastern or Mid-Atlantic dairy farm

\begin{tabular}{|c|c|c|c|}
\hline & & $\mathrm{N}$ & $\mathrm{P}_{2} \mathrm{O}_{5}$ \\
\hline \multicolumn{4}{|l|}{ Farm produced forage } \\
\hline Corn silage & $\%$ of DM & 1.33 & 0.24 \\
\hline Hay & $\%$ of DM & 2.70 & 0.29 \\
\hline Average crop rotation nutrient uptake & $\mathrm{kg} \mathrm{ha}^{-1}$ & 140 & 82 \\
\hline \multicolumn{4}{|l|}{ Nutrients excreted } \\
\hline Per cow & $\mathrm{kg} \mathrm{cow}^{-1}$ & 159 & 45 \\
\hline Per ha ( 2.5 cow ha ${ }^{-1}$ stocking density) & $\mathrm{kg} \mathrm{ha}^{-1}$ & 398 & 113 \\
\hline Difference (excreted less uptake) & $\mathrm{kg} \mathrm{ha}^{-1}$ & 258 & 31 \\
\hline
\end{tabular}

Given production assumptions listed in Table 1 and described in the text.

Table 3. Farm production characteristics of three New York State case study dairy farms

\begin{tabular}{llrrr}
\hline & & Farm A & Farm B & Farm C \\
\hline Milking cows & cows & 471 & 1330 & 105 \\
Animal density & cows ha $^{-1}$ & 1.7 & 2.3 & 1.6 \\
Milk production & $\mathrm{kg} \mathrm{ha}^{-1}$ & 11226 & 20047 & 11062 \\
& $\mathrm{~kg} \mathrm{cow}^{-1} \mathrm{yr}^{-1}$ & 9294 & 12024 & 10366 \\
Purchased feeds & $\%$ & 60 & 41 & 39 \\
\hline
\end{tabular}

\subsection{Whole Farm Balances for Three New York Dairy Farms (Case Studies)}

For the three NY case study farms (Table 3), $65-73 \%$ of the N and $41-62 \%$ of the $\mathrm{P}$ that entered the farm through feed, fertilizer, fixation, animal purchases or bedding did not get exported in the form of milk, animals or crops (Table 4). This resulted in excesses of 114-248 $\mathrm{kg} \mathrm{N} \mathrm{ha}^{-1}$ and 35-42 $\mathrm{kg} \mathrm{P}_{2} \mathrm{O}_{5} \mathrm{ha}^{-1}$. The greatest $\mathrm{N}$ excess per ha occurred at farm $\mathrm{B}$, the farm with the greatest animal density and total number of animals. Manure export lowered the $\mathrm{N}$ balance for farm B from $69 \%$ to $66 \%$ and the P balance from $45 \%$ to $41 \%$. Although farms A and $\mathrm{C}$ had similar stocking density and milk production, a greater reliance on purchased feeds on farm A resulted in higher proportion of excess $\mathrm{N}$ and $\mathrm{P}_{2} \mathrm{O}_{5}$ per land unit for farm A. Farm B's greater stocking density and farm size resulted in the largest farm excess $\mathrm{N}$ and $\mathrm{P}_{2} \mathrm{O}_{5}\left(198 \mathrm{Mg} \mathrm{N} \mathrm{yr}^{-1}\right.$ and $\left.30 \mathrm{Mg} \mathrm{P}_{2} \mathrm{O}_{5} \mathrm{yr}^{-1}\right)$. 
Table 4. Mass nitrogen and phosphorus balances for three New York State case study dairy farms that import $39-60 \%$ of the dry matter fed to the cows and have an animal to cropland density of 1.6 to 2.3 milking cows ha ${ }^{-1}$. Farm characteristics are given in Table 3

\begin{tabular}{llrrrrrr}
\hline & & \multicolumn{7}{c}{ Farm } \\
& & $\mathrm{A}$ & \multicolumn{1}{c}{$\mathrm{B}$} & $\mathrm{C}$ & $\mathrm{A}$ & $\mathrm{B}$ & $\mathrm{C}$ \\
\hline & & \multicolumn{7}{c}{ Nitrogen $(\mathrm{N})$} & & Phosphorus $\left(\mathrm{P}_{2} \mathrm{O}_{5}\right)$ \\
Annual imports & & & & & & & \\
Feed & $\mathrm{Mg} \mathrm{yr}^{-1}$ & 64.93 & 189.30 & 12.19 & 16.45 & 55.18 & 3.59 \\
Fertilizer & $\mathrm{Mg} \mathrm{yr}^{-1}$ & 12.71 & 57.98 & 1.78 & 8.67 & 15.89 & 2.44 \\
N fixation & $\mathrm{Mg} \mathrm{yr}^{-1}$ & 3.45 & 45.14 & 3.29 & - & - & - \\
Animals & $\mathrm{Mg} \mathrm{yr}^{-1}$ & 0.04 & 0.20 & - & 0.02 & 0.12 & - \\
Bedding & $\mathrm{Mg} \mathrm{yr}^{-1}$ & 4.69 & 7.76 & 0.05 & 1.47 & 0.23 & 0.02 \\
Total & $\mathrm{Mg} \mathrm{yr}^{-1}$ & 85.82 & 300.38 & 17.31 & 26.59 & 71.39 & 6.05 \\
Annual exports & & & & & & & \\
Milk & $\mathrm{Mg} \mathrm{yr}^{-1}$ & 21.98 & 80.83 & 5.50 & 9.16 & 33.48 & 2.28 \\
Animals & $\mathrm{Mg} \mathrm{yr}^{-1}$ & 1.56 & 8.02 & 0.63 & 0.87 & 4.46 & 0.35 \\
Crops & $\mathrm{Mg} \mathrm{yr}^{-1}$ & - & 4.55 & - & - & 1.52 & - \\
Manure & $\mathrm{Mg} \mathrm{yr}^{-1}$ & - & 8.91 & - & - & 2.42 & - \\
Total & $\mathrm{Mg} \mathrm{yr}^{-1}$ & 23.54 & 102.31 & 6.13 & 10.03 & 41.88 & 2.631 \\
Import-export & $\mathrm{Mg} \mathrm{yr}^{-1}$ & 62.28 & 198.07 & 11.18 & 16.55 & 29.51 & 3.12 \\
"Remaining" & $\%$ & 73 & 66 & 65 & 62 & 41 & 57 \\
& $\mathrm{~kg} \mathrm{ha}^{-1} \mathrm{yr}^{-1}$ & 160 & 248 & 114 & 42 & 37 & 35 \\
\hline
\end{tabular}

\section{Discussion and Implications}

A summary of $\mathrm{P}$ balances in Pennsylvania (PA), while using a somewhat different approach, estimated that there was an excess of $31 \mathrm{~kg} \mathrm{P}_{2} \mathrm{O}_{5}$ ha $^{-1}$ of cropland in the state (Mid-Atlantic Regional Water Quality Program, 2005), similar to the results obtained with the farm balances in our study. Earlier work in NY by Klausner (1993) and Bloomfield (1998) is consistent with our results as well. Such P surplus is useful when building toward optimum soil test $\mathrm{P}$ levels to maintain yield over time. However, the addition of fertilizer $\mathrm{P}$ as starter or top-dress fertilizer along with manure application over time has resulted in a significant number of fields in the Northeast and Mid-Atlantic regions that no longer exhibit a crop yield response to additional P. In PA, for example, 52\% of the soil tests for agronomic crops are in the above optimum range for P (Agricultural Analytical Services Laboratory, 2005). In NY, 46\% of the samples tested by the Cornell Nutrient Analysis Laboratory in 1995-2001 were high enough in $\mathrm{P}$ to eliminate the need for additional $\mathrm{P}$ or limit applications to no more than a small amount of starter $\mathrm{P}$ (Ketterings et al., 2005). For the long-term sustainabilility of animal agriculture, the $\mathrm{P}$ excess should be address by source reduction, increase of export, or a combination of the two approaches.

Also the N balances are consistent with earlier data by Klausner (1993) and Bloomfield (1998), and studies in other parts of the USA and in Europe (e.g. Nevens et al., 2006; Treacy et al., 2008; Fangueiro et al., 2008). Depending on management, the plant available $\mathrm{N}$ pool may be substantially reduced by urinary $\mathrm{N}$ losses through volatilization of ammonia from the barn floor and from storage (e.g. Bussink \& Oenema, 1998). Substantial losses may also occur once manure is surface applied; depending on dry matter (DM) content, much of the inorganic $\mathrm{N}$ may be lost to the air when manure is surface applied and not incorporated within a couple of days(Meisinger \& Jokela, 2000; Powell et al., 2011). Although current regulations in the USA allows farms to balance $\mathrm{N}$ by accepting these air emissions, such management increases the rate of $\mathrm{P}$ accumulation and will not be sustainable in the long-term. Furthermore, we will be called upon to reduce losses to the air and odor emissions from farmsteads and farm fields (USEPA, 2005). This will include the need for substantial improvements in ammonia-N conservation through e.g. manure incorporation during or shortly after application. Because this change in management requires application rates to be lowered, ammonia conservation helps reduce $\mathrm{P}$ accumulation and losses, but this is not always possible in land-limited situations. One possibility for some 
farms to improve their whole farm $\mathrm{N}$ balance is to substitute grass for alfalfa in the hay portion of the rotation, increasing $\mathrm{N}$ needs for the hay portion of the rotation because grasses do not fix atmospheric N. Impacts of such decisions on whole farm nutrient balances and milk production need to be studied, as there are several practical reasons why many producers in the Northeast and Mid-Atlantic regions prefer alfalfa or alfalfa/grass in the rotation over grass alone (Cornell Cooperative Extension, 1987).

As stocking density and/or reliance on imported feed increase, the difference (surplus) of $\mathrm{N}$ and $\mathrm{P}$ excreted by cows in relation to the $\mathrm{N}$ and $\mathrm{P}$ needs of crops can increase substantially. The stocking density of 2.5 milking cows ha ${ }^{-1}$ selected for our representative farm is modest but illustrative; as this example showed, in the long-term we will need at least 1.5 times as much land for manure application (disposal) than the amount of land needed for forage production (assuming that land application is the only way to manage manure nutrients and that no more $\mathrm{P}$ can be added than removed in harvest). This illustration, for simplicity, considered milking cows only and does not include the nutrient impacts of dry cows and herd replacements. Since most Northeastern and Mid-Atlantic dairy farms also raise their own replacements, the nutrient accumulation may be more dramatic in practice than in this example.

In the past, the desire for manure disposal and concerns about the potential for nitrate leaching to the groundwater and to surface water determined manure application rates (N-based plans). More recently, nutrient management plans in the USA take into account a $\mathrm{P}$ runoff index assessment to minimize $\mathrm{P}$ loss from fields in a way that maximizes management flexibility (Sharpley et al., 2003). The P index is viewed as a practical, effective method of addressing $\mathrm{P}$ runoff related to manure applications because it focuses on critical factors found to impact P loss (Ketterings et al., 2012). However, it is obvious from our studies that the P index does not address the strategic issues at the root of the nutrient management problem; accumulation of excess $P$ resulting in increasing soil test $\mathrm{P}$ levels, unless coupled with manure export strategies.

A growing concern with $\mathrm{N}$ is the potential impact of ammonia volatilized from animal operations (USEPA, 2005). The best approach to reducing the potential for this loss is incorporation of manure following spring application. Compared to other application methods and timing, spring incorporation has important implications for farm nutrient balance and land application. Conserving ammonia $\mathrm{N}$ in the spring increases the amount of $\mathrm{N}$ that is available for crop uptake. Considering the earlier analyses that indicated significant excess $\mathrm{N}$ on many dairy farms, practices such as manure incorporation will reduce allowable manure application rates, increasing the need for land to apply the manure to. If rates cannot be reduced to meet crop needs, reducing ammonia volatilization during field application will increase the risk of $\mathrm{N}$ transport to surface or ground water due to leaching. In addition, incorporation can add a significant economic cost to manure utilization, even considering potential reductions in fertilizer use.

Other issues that are becoming increasingly important considerations in land-application include soil quality, soil conservation, and odor. The latter has become a focal point for potential conflict between some farms and the surrounding community. While these issues are not necessarily directly related to nutrient management, there are critical interactions between many of them. For example, many practices that are used to reduce odor from manure, either from the barn (e.g. frequent scraping, storage) or from field application (e.g. immediate incorporation or injection), will, as pointed out above, result in conservation of a larger proportion of the manure $\mathrm{N}$, thus possibly increasing $\mathrm{N}$ supplied by manure application if rates are not adjusted. Another risk is that manure incorporation to reduce ammonia loss or control odor can increase soil erosion (Maquire et al., 2011). Further research is needed on topics such as injection techniques that can be used in no-till or reduced-till cropping systems.

With increasing environmental pressures, policy makers need to look for economically feasible management options that not just reduce loss of nutrients from farm fields, but optimize nutrient use on the farm, reduce inputs and increase beneficial outputs. This includes development and evaluation of management options that optimize forage quality and animal diets and that adjust crop rotations and stocking densities to soils and nutrient supply (Cerosaletti et al., 2004), and it requires the implementation of a monitoring and reporting system for whoe farm nutrient balances. Addressing air and water quality and $\mathrm{P}$ accumulation issues will require a reduction of manure application rates in many situations. Although this does not necessarily have to lead to an increase in fertilizer costs, manure nutrients that cannot be used in land application may need to be harvested from the manure stream by some combination of treatment processes for export and use off-farm.

At the present time substantial feed grain and forage self-sufficiency could require more land than most dairies currently manage, and this assumes that land suitable for grain production exists nearby. Self-sufficiency in terms of concentrate feeds is currently not a viable option for many dairy farms in the Northeast and 
Mid-Atlantic states because of constraints imposed by a combination of previous expansions, geography/climate, land availability or affordability, and farm economics.

\section{Conclusions}

Assessment of nutrient balances on Northeast and Mid-Atlantic dairy farms illustrated and quantified a dilemma faced by many dairy producers; in many cases, the $\mathrm{N}$ and $\mathrm{P}$ imbalances inherent in these production systems will make it impossible for land-application BMPs alone to solve current and future nutrient management problems. Similar observations were made for intense animal agriculture in other regions of the USA and in Europe. To effectively address the problem of agricultural non-point source pollution, it is critical to recognize that, while individual farm nutrient management tactics are important, the root cause of the problem derives from the strategic organization of modern animal agriculture where a significant portion of feed for the dairy animals is purchased rather than grown on the land that receives the manure. These imbalances between manure nutrients and crop nutrient needs will result in fewer options for manure applications on cropland over time. For the long-term sustainability of the dairy industry in the Northeast and Mid-Atlantic regions, and elsewhere, the BMP approach should be expanded to include nutrient balance assessments and other BMPs that address nutrient source reduction and/or manure treatment and export. The latter requires innovative systems to treat the manure to decrease transport costs and/or add economic value, and above all, a recognition of the importance of adaptive management strategies that include annual monitoring of whole farm balances for refinement and improvement in management over time.

\section{Acknowledgements}

We thank Greg Albrecht, Sheryl Swink, Jason Kahabka, and Liz Brock for critical reviews of an earlier draft of this manuscript. Funding for this work was derived in part from a grant by the NY Department of Agriculture and Markets (contract number C200096), the Northern New York Agricultural Development Program (NNYADP), and a whole farm nutrient balance pilot study supported by the Upper Susquehanna Coalition. An earlier version of this paper was presented at the NRAES Conference entitled "Dairy Manure Management: Treatment, Handling, and Community Relations", held March 15-17, 2005, in Syracuse, NY.

\section{References}

Agricultural Analytical Services Laboratory. (2005). Soil test summaries for agronomic crops 2003-2004.Pennsylvania State University. Retrieved from: http://www.aasl.psu.edu/Agro_Summaries/03_04\%20Agro\%20Sum\%20by\%20p_county.pdf [August 19, 2012].

Bloomfield, S. B. (1998). Nutrient balances of dairy farms in New York State: a case study of five farms with differing production methods. Master of Professional Studies Thesis, Cornell University, Ithaca NY.

Bussink, D. W., \& Oenema, O. (1998). Ammonia volatilization from dairy farming systems in temperate areas: a review. Nutrient Cycling in Agroecosystems, 51, 19-33. http://dx.doi.org/10.1023/A:1009747109538

Cerosaletti, P. E., Fox, D. G., \& Chase, L. E. (2004). Phosphorus reduction through precision feeding of dairy cattle. Journal of Dairy Science, 87, 2314-2323. http://dx.doi.org/10.3168/jds.S0022-0302(04)70053-3

Cornell Cooperative Extension. (1987). Cornell field crops and soils handbook. Cornell University, Ithaca, NY.

Cornell Cooperative Extension. (2012). Cornell guide for integrated field crop management. Media and Technology Services, Cornell University, Ithaca, NY. Retrieved from: http://www.fieldcrops.org [August 19, 2012].

Czymmek, K. J., Ketterings, Q. M., Geohring, L. D., \& Albrecht, G. L. (2003).The New York Phosphorus Index.User's guide and documentation Department of Crop and Soil Sciences Extension Series E03-13. Cornell University, Ithaca, NY.

Dairy One Forage Laboratory. (2006). Field composition library - Corn silage. Accumulated crop years: 05/01/2000 through 04/30/2004. Retrieved from: http://www.dairyone.com/Forage/FeedComp/mainlibrary.asp [August 19, 2012]

Fangueiro, D., Pereira, J., Coutinho, J., Moreira, N., \& Trindade, H. (2008). NPK farm-gate nutrient balances in dairy farms from Northwest Portugal. European Journal of Agronomy, 28, 625-634. http://dx.doi.org/10.1016/j.eja.2008.01.007

Federal Register. (2003). National Pollutant Discharge Elimination System (NPDES). Clean Water Act. Retrieved from: http://cfpub.epa.gov/npdes/cwa.cfm [August 19, 2012]. 
Fox, D. G., Tylutki, T. P., Tedeschi, L. O., Van Amburgh, M. E., Chase, L. E., Pell, A. N., ... \& Russell, J. B. (2003). The Net Carbohydrate and Protein System for evaluating herd nutrition and nutrient excretion. Animal Science Mimeo 213.Department of Animal Science, Cornell University, Ithaca, NY, USA.

Heichel, G. H. (1986). Nitrogen value of legumes in crop rotations. Proceedings on cost-effective forages - the bottom line; Minnesota Forage and Grassland Council, Feb. 26, 1986, St. Paul, Minnesota, pp. 33-37.

Kelling, K. A., \& Smitt, M. A. (2003). Applying manure to alfalfa; pros, cons and recommendations for three application strategies. North Central Regional Research Report 346. University of Wisconsin-Madison. Madison, WI.

Kellogg, R. L., Lander, C. H., Moffitt, D. C., \& Gollehon, N. (2000). Manure nutrients relative to the capacity of cropland and pastureland to assimilate nutrients: Spatial and temporal trends for the United States. USDA-NRCS, USDA-ERS, nps00-0579, GSA National Forms and Publication Center, Fort Worth, TX.

Ketterings, Q. M., \& Czymmek, K. J. (2012). P Index as a P awareness tool: Documented P use reduction in New York State. Journal of Environmental Quality (in press).

Ketterings, Q. M., Czymmek, K. J., \& Swink, S. N. (2011). Evaluation methods for a combined research and extension program used to address starter phosphorus fertilizer use for corn in New York. Canadian Journal of Soil Science, 91, 467-477. http://dx.doi.org/10.4141/cjss10001

Ketterings, Q. M., Kahabka, J. E., \& Reid, W. S. (2005). Trends in phosphorus fertility of New York agricultural land. Journal of Soil and Water Conservation, 60, 10-20.

Ketterings, Q. M., Klausner, S. D., \& Czymmek, K. J. (2003). Nitrogen guidelines for field crops in New York (2nd Ed.).Department of Crop and Soil Sciences Extension Series E03-16.Cornell University, Ithaca, NY.

Ketterings, Q. M., Swink, S. N., Godwin, G., Czymmek, K. J., \& Albrecht, G. L. (2005). Maize silage yield and quality response to starter phosphorus fertilizer in high phosphorus soils in New York. Journal of Food, Agriculture and Environment, 3, 360-365.

Klausner, S. D. (1993). Mass nutrient balances on dairy farms. In Proceedings of the Cornell Nutrition Conference for Feed Manufacturers, Rochester, NY: Cornell University, Ithaca, NY.

Kleinman, P. J. A., Bryant, R. B., Reid, W. S., Sharpley, A. N., \& Pimentel,D. (2000). Using soil phosphorus behavior to identify environmental thresholds. Soil Science, 165, 943-950. http://dx.doi.org/10.1097/00010694-200012000-00004

Knowlton, K. F., \& Herbein, J. H. (2002). Phosphorus partitioning during early lactation in dairy cows fed diets varying in phosphorus content. Journal of Dairy Science, 85, 1227-1236. http://dx.doi.org/10.3168/jds.S0022-0302(02)74186-6

Kohn, R. A., Dou, A., Ferguson, J. D., \& Boston, R. C. (2002). A sensitivity analysis of nitrogen loss from dairy farms. Journal of Environmental Management, 50, 417-428. http://dx.doi.org/10.1006/jema.1997.0133

Lanyon, L. E. (2000). Nutrient management: Regional issues affecting the Bay. In: A.N. Sharpley (ed.). Agriculture and phosphorus management - The Chesapeake Bay, 145-168, Lewis Publishers, Baco Raton, FL.

Maguire, R. O., Kleinman, P. J. A., Dell, C., Beegle, D. B., Brandt, R. C., McGrath, J. M., \& Ketterings, Q. M. (2011). Manure application technology in reduced tillage and forage systems; a review. Journal of Environmental Quality, 40, 292-301. http://dx.doi.org/10.2134/jeq2009.0228

Maguire, R. O., \& Sims, J. T. (2002). Measuring agronomic and environmental soil phosphorus saturation and predicting phosphorus leaching with Mehlich 3. Soil Science Society of America Journal, 66, 2033-2039. http://dx.doi.org/10.2136/sssaj2002.2033

McDowell, R. W., \& Sharpley, A. N. (2001). Approximating phosphorus release from soils to surface runoff and subsurface drainage. Journal of Environmental Quality, 30, 508-520. http://dx.doi.org/10.2134/jeq2001.302508x

Meisinger, J. J., \& Jokela, W. E. (2000). Ammonia volatilization from dairy and poultry manure. In NRAES-130, Proceedings Conference Managing nutrients and pathogens from animal agriculture, (pp. 334-354). Ithaca, NY; NRAES.

Mid-Atlantic Regional Water Quality Program. (2005). Nutrient budgets for the Mid-Atlantic States. Retrieved from: http://mawaterquality.psu.edu/ [August 19, 2012]. 
National Agricultural Statistics Service. (2006). New York State Agricultural Statistics. Retrieved from: http://www.nass.usda.gov/Publications/Reports_By_Date/index.asp [August 19, 2012].

Nevens, F., Vervruggen, I., Reheul, D., \& Hofman, G. (2006). Farm gate nitrogen surpluses and nitrogen use efficiency of specialized dairy farms in Flanders: Evolution and future goals. Agricultural Systems, 88, 142-155. http://dx.doi.org/10.1016/j.agsy.2005.03.005

Pennsylvania State University. (2012). The Penn State Agronomy Guide. Publications Distribution Center, University Park, PA. Retrieved from: http://extension.psu.edu/agronomy-guide [August 19, 2012].

Powell, J. M., Jokela,W. E., \& Misselbrook, T. H. (2011). Dairy slurry application method impacts ammonia emission and nitrate leaching in no-till corn silage. Journal of Environmental Quality, 40, 383-392. http://dx.doi.org/10.2134/jeq2010.0082

Sharpley, A. N., McDowell, R. W., Weld, J. L., \& Kleinman, P. J. A (2001). Assessing site vulnerability to phosphorus loss in an agricultural watershed. Journal of Environmental Quality, 30, 2026-2036. http://dx.doi.org/10.2134/jeq2001.2026

Sharpley, A. N., Weld, J. L., Beegle, D. B., Kleinman, P. J. A., Gburek, W. J., Moore, P. A., \& Mullins, G. (2003). Development of phosphorus indices for nutrient management planning strategies in the United States. Journal of Soil and Water Conservation, 58, 137-152.

Sims, J. T., Maguire, R. O., Leytem, A. B., Garthley, K. L., \& Pautler, M. C. (2002). Evaluation of Mehlich 3 as an agri-environmental soil phosphorus test for the Mid-Atlantic United States of America. Soil Science Society of America Journal, 66, 2016-2032. http://dx.doi.org/10.2136/sssaj2002.2016

Thompson, R. B., \& Meisinger, J. J. (2001). Management factors affecting ammonia volatilization from land-applied cattle slurry in the Mid-Atlantic USA. Journal of Environmental Quality, 31, 1329-1338. http://dx.doi.org/10.2134/jeq2002.1329

Treacy, M., Humphreys, J., McNamara, K., Browne, R. V., \& Watson, C. J. (2008). Farm-gate nitrogen balances on intensive dairy farms in the south west of Ireland. Irish Journal of Agricultural and Food Research, 47, 105-117.

United States Environmental Protection Agency. (2005). Air quality agreement with animal feeding operations. Retrieved from: http://www.epa.gov/Compliance/resources/agreements/caa/cafo-agr-0501.html [August 19, 2012]

USDA-NRCS. (2005). Electronic field office guide. Retrieved from: http://www.nrcs.usda.gov/technical/efotg/ [August 19, 2012]

USDA-NRCS. (2006). Financial and technical assistance available to concentrated animal feeding operation owners and operators. Retrieved from: http://www.nrcs.usda.gov/programs/afo/CAFO_AsstAvail.html [August 19, 2012] 